\title{
História dos indios na América: abordagens interdisciplinares e comparativas
}

Entrevista com Serge Gruzinski *

Entrevistadora: Maria Regina Celestino de Almeida

1. Os estudos sobre populações indígenas nas Américas têm se desenvolvido numa perspectiva histórico-antropológica que tende a valorizar os índios como sujeitos ativos dos processos históricos nos quais se inserem. Seu trabalho sobre o México colonial insere-se nessa linha de pesquisa, assim como os trabalhos apresentados neste dossiê. Como vê a importância da abordagem interdisciplinar para esses estudos e, de forma mais ampla, para a própria história indígena das Américas?
SG - A abordagem interdisciplinar começa com os primeiros estudos sobre os índios do México e Peru. São estudos sobretudo etno-históricos, e já a palavra pressupõe este tipo de produção híbrida e de encontro entre a história e a antropologia. No México, por muito tempo, os índios eram objeto da etno-história, a história era para os brancos. Uma referência importante no caso do México é Gonzalo Aguirre Beltrán, antropólogo que faz história. Aplica a teoria da aculturação (da antropologia cultural norte-americana) a um contexto

* Diretor de Pesquisa da CNRS e Diretor de Estudos da École des Hautes Études em Sciences Sociales - França. 
histórico que cobre todo o período colonial, o século XIX e a revolução mexicana. Combina uma visão antropológica com uma visão diacrônica do passado. Para o Peru e para o México a etno-história foi a base dos estudos sobre os índios. Nathan Wachtel é outro historiador que combinou conhecimento profundo dos arquivos com o trabalho de campo intensivo, cujo melhor resultado é o seu livro Le Retour des Ancêtres - Les Indiens Urus de Bolivie XXe-XVIe siècle. É um estudo sobre os Urus, com os quais passou muito tempo no lago Titicaca. No meu caso, quis estudar a história dos índios do México porque isso me obrigava a combinar enfoques antropológicos e históricos. E posso acrescentar também arqueológicos, já que muitos dos dados desses índios vêm de fontes arqueológicas.

\section{De qualquer forma, parece que} mesmo no caso da história indígena dessas regiões, nas quais esses estudos tiveram sempre abordagens interdisciplinares, mantinhase, como você afirmou, uma certa distinção entre uma etno-história dos índios e a história dos brancos. Isso ainda se mantém? Como vê as possibilidades de superar esse dualismo?
SG - Hoje, a linha de demarcação já não se impõe pela hegemonia da história dos brancos, mas pela preocupação dos historiadores de privilegiar as vozes dos índios, ou seja, uma história que seria totalmente enfocada não só sobre o protagonismo dos índios, mas também sobre as fontes escritas de origem indígena. Essa visão radical rechaça o ponto de vista europeu e as fontes européias, contribuindo para manter separada a etno-história dos índios das histórias dos outros grupos que compunham as sociedades coloniais.

3. Considerando as significativas diferenças entre as diversas regiões da América em relação às populações indígenas e seus contatos com as sociedades envolventes, assim como a multiplicação de estudos regionais que revelam exatamente essas diferenças, gostaria de colocar duas questões. Como vê as possibilidades de estudos comparativos entre as diferentes regiões da América? Como vê a importância de estudos de caso?

SG - A experiência ensina que é difícil promover estudos comparativos entre as diferentes regiões da América. Existem obras que reúnem contribuições da Meso-América e dos 
Andes, mas são mais justaposições que comparações entre elas, procurando confrontá-las. Talvez seja mais fácil comparar processos. Por exemplo, seria muito interessante comparar processos de mestiçagem entre índios mexicanos e andinos. Essa dificuldade reflete um problema muito mais geral, que é a compartimentalização entre as disciplinas, as historiografias e as antropologias latino-americanas. Outra possibilidade seria comparar situações que se assemelham nos processos de integração dos índios nas nações do século XIX ou no processo de redescobrimento dos índios na Argentina ou no Brasil, no século XX e princípios do XXI. Logo, seria melhor comparar situações e processos, em vez de casos, zonas, etnias. Comparar problemáticas, como o desaparecimento e reaparecimento dos índios, por exemplo.

\section{Seus estudos recentes têm en-} fatizado a importância das abordagens globalizantes que, ao promover as possíveis articulações entre eventos diversos em regiões distantes, e até em tempos distintos, lhes conferem significados mais amplos e complexos. Como vê as possibilidades de articulação entre a história indígena e essa história globalizante?

SG - É importante não reduzir o termo indígena ao seu sentido ame- ríndio. Pensar que o indígena pode ser também o africano, o filipino, o marroquino, Enfim, todos os que tiveram de reagir às ofensivas comerciais, à cristianização, à dominação política dos ibéricos, fossem portugueses ou espanhóis. Um ponto comum a todos esses grupos tem a ver com o processo de ocidentalização e com as múltiplas formas de responder a este processo. Nós não podemos desvincular as modalidades de cristianização dos índios do Brasil pelos jesuítas com as praticadas em outras regiões. Para entender as especificidades do Brasil é preciso pensar como isso se passou na Índia porque são processos sincrônicos que incluem o jogo duplo da colonização política e religiosa. Ambos buscavam a transformação do índio em cristão. Este tipo de comparação não é nada arbitrário porque os mesmos jesuítas circulavam em todas as partes do império português e até fora do Império. Por exemplo, o primeiro capelão da Igreja de N. Sra. de Guadalupe, perto da cidade do México, provinha de Goa, onde antes tinha sido sacerdote. Isso quer dizer que o mesmo homem transferiu sua experiência com os indígenas da Ásia para os indígenas da América espanhola. As histórias conectadas estudam conjuntos continentais ligadas por circulações, intercâmbios, experiências comuns.

Paris, 26 de maio de 2006 